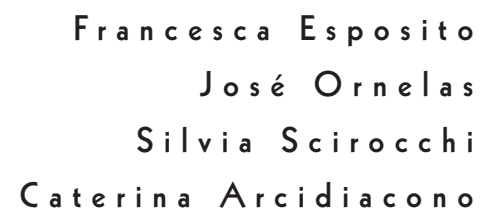

\title{
Voices from the Inside: Lived Experiences of Women Confined in a Detention Center
}

U

nder conditions of mass mobility, migration-related detention has be-

come part of a set of border control measures that are implemented in the majority of countries across the world, particularly in the global North (Bosworth 2014; Bosworth and Kellezi 2014). The proliferation of border zones and detention centers - where various categories of people marked as outsiders are confined pending the adjudication of their statusplays a key role in the government of human mobility and in the continuous production of nation-state and citizenship boundaries (Luibhéid 2005).

In spite of growing academic interest in the adverse effects of detention and deportation (e.g., Sobhanian et al. 2006; Robjant, Robbins, and Senior 2009), relatively little attention has been paid to the potential relationships between the violence that affects people in their countries of origin and contemporary immigration laws and policies (Lykes and Hershberg 2015). Even less effort has been devoted to understanding how gender and sexualityalong with race, ethnicity, class, nationality, and geopolitics - shape such relationships, playing a role in the production of particular subjects as excludable and deportable (Lewis 2013). As Eithne Luibhéid (2005) clearly notes, multiaxial differentiations that operate through immigration control regimes not only distinguish citizens from noncitizens but also discriminate among noncitizens themselves, stemming from and reinforcing normative power hierarchies.

This research was carried out as a part of Francesca Esposito's doctoral thesis, supported by a scholarship from the Portuguese Foundation for Science and Technology (SFRH/BD/ $87854 / 2012$ ). We would like to thank Maayan Ravid, Rimple Mehta, Gaia Giuliani, Simone Tulumello, and Erica Briozzo for their encouragement for this project by offering their time and insightful feedback, as well as Signs's editor and anonymous reviewers who provided critical comments on this article. We also need to thank the organizers and participants of the workshop "Critical Prison Studies, Carceral Ethnography, and Human Rights: From Lived Experience to Global Action," held at the Oñati International Institute for the Sociology of Law, where we presented an earlier version of this article, for their generous input and comments. Last, and most important, we are grateful to the BeFree team and to the women we met inside Rome's detention center for sharing their stories and struggles with us. 
According to a structural violence perspective (Galtung 1969), political, economic, cultural, and social forces at work in various global contexts structure risk for human suffering, determining who suffers violence, how much violence is suffered, and which forms of violence are considered acceptable or legitimate. In particular, in the present article we document and analyze structural violence from a feminist perspective. From this viewpoint, we focus our attention on the structural violence embedded in the heteropatriarchal structures of mainstream society, which are deeply imbricated with the politics of racism and white supremacy. This perspective appears to be particularly relevant for an empirical understanding of the lived experiences of women subject to policies and practices of immigration and border control, particularly those incarcerated inside detention centers.

Drawing on two years of fieldwork, informed by a community psychology ecological perspective with a focus on justice (Esposito, Ornelas, and Arcidiacono 2015b), the purpose of this article is to provide insight into the experiences of the women confined inside Rome's detention center. ${ }^{1}$ In so doing, we embrace a feminist framework that favors the perspectives of women, whose voices have historically been excluded from the process of knowledge production (see Personal Narratives Group 1989; Harding 2004), as well as from discussions regarding border control regimes (Bosworth, Fili, and Pickering 2014; Mehta 2016). Feminist analyses have long highlighted the centrality of women's experiences and narratives in order to contest the hegemonic notions of knowledge that, while presented as objective and value-free, are predominantly based on a "Western, bourgeois, white-supremacist, androcentric, heteronormative culture" (Harding 2004, 5). Such experiences, and the related struggles, have also been claimed as a starting point for progressive politics (Mohanty 1995, 2003).

A close reading of the stories of our participants, in their contradictions and ambiguities, draws attention to the nature and impacts of immigration and border regimes and their operation as mechanisms of differential inclusion across lines of sex and gender, among other factors (Andrijasevic 2009, 2010). Further, in illustrating how women strive to negotiate, manipulate, and resist disciplinary and regulatory mechanisms and normative power structures, the data from this research may shed some light on the debate surrounding the dialectic between power and subordination, domination, and resistance.

\footnotetext{
${ }^{1}$ This fieldwork is a part of a larger study of life within detention centers in Italy and Portugal. Such a study constitutes Francesca Esposito's doctoral research in community psychology.
} 


\section{An overview of the Italian context of detention}

Migration-related detention in Italy has relatively recent origins, dating to the late 1990s, which saw the opening of the first detention center. ${ }^{2}$ At the time of this writing, there are four operational detention centers, currently referred to as Centri di Permanenza per i Rimpatri (accommodation centers for repatriation) and ex-Centri di Identificazione e Espulsione (identification and expulsion centers) located in Rome, Turin, Caltanissetta, and Brindisi. ${ }^{3}$ In such centers, people whose expulsion orders cannot be immediately enforced are confined while they wait to be identified and eventually deported. Heterogeneity is the predominant feature of the population of detainees, which encompasses migrants who have just landed on Italian shores; long-term residents with family ties in the country, including people who have grown up or were even born in Italy; ex-offenders coming directly from prison; people whose employers never filed the appropriate paperwork or who failed to renew the residence permit due to loss of employment; asylum seekers; and even EU citizens considered "a threat to public order and security" (Campesi 2015).

Under the law enforced at the time of this writing (Law No. 161/2014), the maximum term for detention is ninety days, and thirty days in the case of foreign nationals who have already spent three months or more in prison. ${ }^{4}$ However, Legislative Decree No. 142/2015, implementing the EU Asylum Procedures and Reception Conditions Directives, established a period of detention of up to twelve months for asylum seekers who "constitute a danger to public order and security" and for whom "there is a risk of absconding."

Rome's Ponte Galeria center is the largest Italian detention facility. Located in a southwest suburb, close to Fiumicino International Airport, the facility is prison-like, with the perimeter surrounded by high walls and fences, and with surveillance cameras scattered throughout the various areas. The center is managed by a private entity by means of public funding.

In 2016, the center's capacity (originally 354 people-176 men, 178 women) was radically reduced as a consequence of a protest that resulted in a fire in the male living unit. Since then, Ponte Galeria has been an allwomen's detention center that can hold up to 125 women subject to a detention order. It is in this scenario that our research took place.

\footnotetext{
${ }^{2}$ For a historical overview of the Italian legal and policy framework on detention, see, e.g., Esposito, Ornelas, and Arcidiacono (2015a).

${ }^{3}$ Law No. 46, recently approved by the Italian Parliament, mandates the expansion of the detention network to increase deportations. According to this law, detention facilities will be established in every Italian region.

${ }^{4}$ Until November 2014 detention in Italy was up to eighteen months.
} 


\section{A note on methodology}

This article is based on fieldwork conducted in Rome's center between March 2014 and April 2016 (taking approximately 588 hours). In particular, Francesca Esposito conducted interviews with twenty-nine detained women to gain an understanding of their lived experiences. Interviews were conducted in a conversational style and usually took the form of a life story. In general, they were digitally recorded and transcribed verbatim.

For the purpose of this article, we decided to analyze the stories of five participants who represented much of the diversity in the larger sample in terms of backgrounds and experiences. These stories were analyzed through a thematic narrative approach (Riessman 2008). We read the transcripts several times and created chronological biographical accounts. Each member of the research team reviewed these accounts in order to focus on and discuss the crucial topics and episodes around which the women organized their narratives. In a further step, we investigated continuities and discontinuities within and across stories (Lykes and Hershberg 2015).

As with the work of the community psychologists M. Brinton Lykes and Rachel Hershberg, our research was informed by "a methodological commitment to documenting links between social structures and systems that produce and impinge on the lives of participants, as well as a commitment to identifying the ways in which participants make sense of (and resist) these systems" $(2015,248)$. Such an analysis provides a meaningful alternative to individualistic readings of the effects of violence, bringing to light the political dimension of women's experiences.

Furthermore, our research adopted a feminist framework that acknowledges fuzziness and vagueness as constitutive dimensions of the research process, as well as the existence of intrinsic power imbalances in the researcherparticipant relationship (Mehta 2016). With this in mind, we favored a critical reflexive attitude as a way of engaging with the research experience (see Esposito 2017). Such an attitude also encompasses an awareness that our positionality - as white psychologists from countries in the European Union, and thus as outsiders to the experiences of the women interviewed-deeply informs how and what we have been able to understand through the analytical process.

\section{Narrative analysis}

As a result of the analytical process, two main categorical themes emerged: violence and oppression, and agency and resistance. In accord with other feminist scholars, we opted to not conceive of these two themes in binary terms but rather as interconnected dimensions in the experiences of our partici- 
pants. ${ }^{5}$ As Arlene Elowe MacLeod $(1992,534)$ passionately argues, women, "even as subordinate players, always play an active part that goes beyond the dichotomy of victimization/acceptance, a dichotomy that flattens out a complex and ambiguous agency in which women accept, accommodate, ignore, resist, or protest-sometimes all at the same time." From a feminist view, deconstructing dominant narratives by reversing binaries — such as that of the victim/agent - is a crucial way of providing room for alternative conceptions and new forms of politics (Wibben 2011).

Embracing this standpoint, we decided to focus our analysis on understanding the intertwinement between oppression and resistance in the narratives of the women we interviewed. Further, we sought to acknowledge the intersections of gender, sexuality, race, class, and other structural determinants that shape women's experiences in context (Gerard and Pickering 2014). The results of our analysis are described below.

\section{Contexts of origin and struggles for mobility}

In their countries of origin, migrant women often experience abuse and restrictions related to gender- and sex-based prescriptions and struggle against heteropatriarchal norms that undermine their right to freedom and selfdetermination. Women describe family conflicts due to the subversion of gender and sex roles, gender-based violence, and situations of poverty in which the burden of financial support is delegated to women as common motives underlying their decision to migrate (Beretta et al. 2016).

Najwa, a twenty-two-year-old Canadian woman born to a Palestinian father and a Lebanese mother, recounted that, when she was thirteen, in accord with Lebanese Muslim tradition, her family selected a Muslim Lebanese man for her to marry. ${ }^{6}$ When she moved from Canada to Lebanon, Najwa began to meet her candidate, but during these meetings he revealed a violent disposition. Najwa's courageous decision to break off the engagement was not well received by her mother, who wanted her to respect the tradition. Consequently, she refused to approve any other candidate, a situation Najwa endured until she fell in love with an Iraqi man. At that time she was living and working in Qatar, where she had moved with her mother after her father's death. It was when her mother rejected the man she loved that Najwa decided to migrate to Europe, to be free to love without constrictions. In the

${ }^{5}$ See, e.g., MacLeod (1992), Shefer (2015), Campbell and Mannell (2016), and Turan et al. (2016).

${ }^{6}$ Given the conditions of induced vulnerability (Butler, Gambetti, and Sabsay 2016) to which the women we interviewed were exposed, prior to and within detention, participants' real names have been replaced by pseudonyms. 
case of Najwa, as well as in the stories depicted by Alexandra D'Onofrio in L'amore ai tempi della frontiera (Love in the time of the frontier; 2012), love was both the driving force of her mobility and a form of resistance against border control: "He's the guy that I chose, and I wanted him to come to propose to me and everything," Najwa said. "She [the mother] said 'no,' of course, that was the reason to leave Qatar with him, to come to Europe."

From Italy, where they first arrived in Europe, Najwa and her husband moved to Switzerland to seek asylum there. In order to not be separated from her partner, Najwa lied to the Swiss immigration authorities, declaring herself to be Syrian rather than Canadian and thus eligible for international protection. However, the Swiss government, according to the Dublin Regulation, denied Najwa's husband's asylum application on the grounds that he had first entered Italy. ${ }^{7}$ As a consequence, the couple tried to escape to France but were arrested by the Swiss police. During our interview with her, Najwa stressed how police officers stopped them because of their visible Middle Eastern origins. Najwa suffered inhumane treatment in prison and was not permitted to contact the Canadian embassy.

Deported to Italy, the competent state for the analysis of Najwa's husband's asylum application, the couple were handed over to the Italian border police. At that time Najwa's Canadian passport had expired, and she did not have any other documents with her. They spent five days at Fiumicino Airport without being able to take a shower or sleep in a bed, eating only one meal a day. Afterward, Najwa was called by a police officer, who forced her to sign some papers that she did not understand, as they were written in Italian. He did not give any explanation of what was happening and threatened to separate her from her husband if she refused to sign. Following this, Najwa was taken to Rome's detention center. She recalled:

This man came and he was absolutely rude ... he didn't even explain what's written on the paper, it was written in Italian, not in English, and he told me to sign. I told him: "I'm sorry I'm not gonna sign something I don't understand," and because of that he was shouting at me. . . I I couldn't do anything because I was crying, and I told them: "Okay, I will sign if you let me see my husband." He said, "No, you missed your chance, you're going to jail and you will not see your husband."

7 The Dublin Regulation (EU Regulation No. 604/2013) establishes the criteria and mechanisms for determining the member state in charge of examining an application for international protection lodged by a third-country national or a stateless person in one of the member states. According to this regulation, the application is to be presented in the first European country in which the person arrives and where they were identified by local authorities. 
In spite of the variations in individual stories, in all of the narratives of the women we interviewed (with the exception of Mirela, who was born and grew up in Italy), migration was an outcome of their struggles against the structural inequalities that shaped their lives in their contexts of origin. As Janet Turan and her colleagues $(2016,161)$ highlight when speaking about pregnant women in Kenya, "migration can be a 'choice,' an expression of agency. But even when forced, migration is often the result of an act of resistance on the part of the woman." This was also true in the case of the women whose stories are narrated in this article. Their migration was "not always, or only, undertaken for survival, but also in pursuit of preservation of dignity and an expansion of life choices" (Turan et al. 2016, 155). In particular, while economic hardship was a theme mentioned frequently by our participants, other motives and desires emerged to inform their migratory projects (such as improving financial situations, seeking autonomy from abusive family contexts, gaining opportunities to live a free and full life, and to love). As Rutvica Andrijasevic (2010, 139) notes in commenting on her interviews with migrant women working in the sex industry in Italy, "a feeling of being 'stuck' in life or the desire to find a partner or love are equally important as economic hardship in capturing the reason why people migrate." This is what emerges from the story of Najwa, who, like some of the women Andrijasevic met, chose to leave the country where she was living to be able to freely and fully live her emotional life. Acknowledging the multiplicity of contexts, needs, and desires that informed our participants' migration means looking at migrant women as complex subjects seeking, and struggling for, a change in their lives (Andrijasevic 2010).

\section{Crossing borders}

Work, student, and even tourist visas to come to countries of the global North are often difficult to obtain, particularly for those with limited or no financial resources. Therefore, many women, especially from sub-Saharan African countries, often have no alternative but to undertake long and troubled journeys toward their European destinations, thus becoming commodities for the lucrative industry of "illegal" border crossing. During such journeys, they are exposed to violence and violations. In some cases, they can even risk their lives (Freedman 2015). From this viewpoint, as Alison Gerard and Sharon Pickering assert, transit can be understood as "a period of direct and structural violence" $(2014,353)$ that targets particular racialized and gendered bodies. This cycle of violence is upheld and enhanced by the increasing securitization of borders cultivated by the EU (Gerard and Pickering 2014; see also Andrijasevic 2010). 
Twenty-six-year-old Precious, who journeyed to Italy from Nigeria, had to quit her studies and look for a job when she lost her parents at the age of twelve. Given her condition of economic vulnerability and her desire to financially support her brothers and sisters, she decided to accept the proposal of an acquaintance to travel to Europe to work. From her narrative, it is not clear how much information she had about what the work involved. The journey Precious endured - through Nigeria, Niger, and Libya — was characterized by serious human rights violations. Niger is a major transit country for West and Central African migrants journeying toward Libya and Algeria. There, local criminal networks are intertwined with transnational networks and, with the connivance of the police, they make the migrant crossing a profitable business (Zandonini 2016). The crossing of the Sahara Desert represents a particularly painful stage of the journey, a perilous passage full of raids and violence during which many migrants die (Del Grande 2008). There, Precious witnessed the death of two people due to the lack of food and water; their bodies were abandoned in the desert along with the remains of other migrants who had faced the same fate. These people are the new desaparecidos, asesinadosy muertos (disappeared, assassinated, and dead; Stephen 2008). "In the desert," Precious recalled, "so many dead people on the ground, Nigerian people who died, with their family they are looking for them. . . So we spent ... . three, four days in the desert, without eating, no bath, nothing. Everybody smelt like a dead person, we were happy that we didn't die... two people died on the trip, so it was really terrible."

During the journey, Precious was the victim of sexual violence. Sexual violence from armed gangs or private militias is the everyday reality for many women traveling across the Sahara to Libya (Gerard and Pickering 2014; Amnesty International 2015; Beretta et al. 2016). As the work with refugee women developed by Camille Schmoll (2014) and by Alison Gerard and Sharon Pickering (2014) reveals, exposure to danger and violence during transit is mediated by access to finances as well as by gender. These analyses highlight how the ability to meet the demand for money from state and nonstate actors involved in the border crossing industry may reduce the risk for women and men to be exposed to direct violence, enhancing their ability to negotiate it. When women lack financial resources, their bodies can serve as a form of currency for negotiating a border crossing (Gerard and Pickering 2014; Beretta et al. 2016). However, the availability of money, as Precious's accounts unveils, does not always protect migrants from violence, which for women usually takes the form of sexual abuse. Hence, rape is the border toll paid by many women traveling to Europe through this route, regardless of the amount of social and material resources to which they have access: "Before we enter [the southern Libyan city of Al] Qatrun," Precious said, "these 
army people, they're holding gun[s], they asked all of us to come down again [from the truck], and it was night, midnight they came. They were asking: 'Where are you going to?,' 'What are you going to do in Europe?'. . they were saying it in aggressive way ... they [the men] gave them some money ... they beat them all, and some of the girls, they take them inside to rape them also." Rape, as "a technology that reproduces gender and sexual hierarchies and norms on the one hand and racial and class divisions on the other" (Andrijasevic 2009, 393), constitutes a way of inscribing the border on the bodies of women.

Upon her arrival in Libya, Precious spent several days locked in a connection house where her movements were controlled. In Lybia, migrants are subject to abuse and exploitation, and if they complain to the police, they are usually ignored (Amnesty International 2015). Moreover, they are continuously at risk of detention (Gerard and Pickering 2014; Schmoll 2014). Such heightened exposure to violence, which differentially affects people across lines of race, color, culture, and religion, as well as sex and gender, produces a sense of constant insecurity and fear, and it reduces migrants' everyday access to public space. In particular, women often rely on domestic or sex work, enduring conditions of severe exploitation in order to pay for the final part of their journey to Europe, which involves crossing the sea (see Gerard and Pickering 2014; Beretta et al. 2016). In the case of Precious, her journey through the Mediterranean, which she referred to as "the river," lasted three days, until her precarious boat was rescued as it was leaking. Unfortunately many migrants are not rescued, and it is estimated that nearly fifteen thousand people have lost their lives in the Mediterranean since the beginning of 2013 (IOM 2017). ${ }^{8}$

From Sicily, where she landed, Precious reached the house of her $\mathrm{Ni}$ gerian madam in Turin. Once there, the woman told her that she had a travel debt of 35,000 euros, which could only be paid through sex work. Violence and abuse characterized her daily life. When Precious got pregnant, her madam ordered her to abort, but Precious refused to take the drugs she was given. Forced to leave her baby in the hospital, she continued to struggle womanfully to find her. To pursue this goal and to free herself from violence, Precious decided to escape the madam's house, even though this meant risking her life. To

\footnotetext{
${ }^{8}$ The International Organization for Migration's Missing Migrants Project notes that "total deaths on the Mediterranean this year [January 1-June 21, 2017] now stand at 2,108. Although that total is more than 800 fewer than the number of deaths that were recorded at this time last year, it nonetheless marks the fourth consecutive year migrant deaths on the Mediterranean Sea have exceeded 2,000 and brings the total number of deaths on the Mediterranean since early 2013 to nearly 15,000 - or a daily average of 10 men, women and children since this current emergency began" (IOM 2017).
} 
do this, she relied on the support of a Nigerian friend. Having been informed by other migrants that the route from Milan to Chiasso (a Swiss city on the Italian border) was not closely controlled by the police, she took a train to the Chiasso station and declared herself as an asylum seeker in front of the Swiss border police.

Precious's asylum claim was denied, first by the Italian authorities, who did not recognize her experience in Nigeria as grounds for asylum, and then by the Swiss authorities, who refused her application according to the Dublin Regulation. Stopped by Swiss police on a train, probably because of her blackness, Precious was detained and taken back to Italy. In Italy she was held in Turin's detention center. It was there that Precious found the courage to tell her story of abuse, violence, and exploitation to a staff member. However, in spite of the existence of specific legal provisions, Precious was deported back to Nigeria. ${ }^{9}$ After she reemigrated to Italy, Precious gave a false name and tried to seek asylum again, but since her fingerprints had already been registered, her true identity was discovered..$^{10}$ This is how, without receiving much explanation, she was detained again, this time in Rome's center.

Among our participants, Precious's journey was certainly the most difficult. Even though many of the women faced difficulties in moving away from their countries of origin, they were not exposed to the same levels of violence, and they managed to obtain passports and travel visas. ${ }^{11}$ This evidence sheds light on the different mobility of distinct groups of dispossessed subjects, which is also a reflection of the regime of differential mobility implemented by the EU through a complex set of devices and measures (Rigo 2005; Andrijasevic 2010). Furthermore, it shows how the apparatus of immigration control (re)produces interlocking systems of oppression-sexual, gender, racial, class, and geopolitical- "that comprise the building blocks of national, transnational, and imperial relations of power" (Luibhéid 2008b, 299).

As Jennifer Hyndman notes in her book Managing Displacement: Refugees and the Politics of Humanitarianism, "how human displacement is de-

\footnotetext{
${ }^{9}$ Article 18 of Legislative Decree 286/1998 (Italian Immigration Law) provides a program of social integration and rehabilitation for victims of violence and severe exploitation. It also grants those participating in the program a temporary residence permit (six months renewable for one further year), which can be converted into a study or work permit. For a critical analysis of this measure, see Andrijasevic (2010).

${ }^{10}$ The European Union maintains a database containing the fingerprint data of asylum seekers and undocumented migrants.

${ }^{11}$ On the relationship between documented/undocumented forms of travel and risk of violence, see Andrijasevic (2010).
} 
fined and managed depends on historically specific configurations of geopolitics, as well as on cultural and economic relations of power" $(2000,32)$. Hyndman thus draws particular attention to the "economies of money, power, and space" (32) that unevenly shape mobility within and across migrant groups. In the story of Precious, if access to financial means (via the intersection of class and gender) emerged to shape her - and others' - experience of mobility, geopolitics played an important role too. The geographical location of migrants' struggles to access sovereign territory, which reflect "the routes traveled by people on the move and the places where they encounter authorities" (Mountz 2011, 382), are pivotal to the examination of subjective experiences of transnational mobility. By drawing on transnational feminist scholarship (e.g., Mountz 2011), we refer to the importance of looking both at the contextual (geographical location) and the historical dimension of people's struggles for mobility, including imperialism and colonization, as well as people's resistance against them. Historicization thus refers to the historical, material circumstances that connote migrants' struggles to access sovereign territory. In particular, this sheds light on the distinct "material topographies of exclusion" (Mountz 2011, 385) that are written onto the gendered and racialized bodies of migrants through their exposure to border posts, detours, interruptions, incarcerations, and returns. These topographies, however, are not to be understood as fixed but rather as continuously redrawn through the daily struggles of people who, like Precious, are in pursuit of geographic, affective, economic, and social mobility (Andrijasevic 2010).

\section{Making a living in Italy}

\section{Exploitation and violence in labor}

The employers did not pay me properly, everybody knew I was on my own. I have no documents, I can't make a complaint, nothing!

-Margarita's story

When migrant women arrive in Italy, things are not usually as they had imagined. Race, class, gender, and sex hierarchies and prescriptions continue to strongly affect their lives, which are frequently marked by violence and marginalization. In some cases, moving to a new country can even exacerbate gender-linked vulnerabilities and powerlessness (Narayan 1995). For instance, among our participants, exposure to racialized and gendered violence emerged as a common experience. However, the threat of being expelled and deported prevented the women from reporting crimes to the police. Thus, abusive employers and partners were able to take advantage of the women's 
undocumented status to keep them in a position of enforced vulnerability and exploitation.

Margarita, who was thirty-two when we interviewed her, left her family home in Ukraine and started to work as a way of rebelling against her parents' decision to marry her off when she was seventeen. However, wages for women in Ukraine are relatively low (compared with those for men) and are usually insufficient to support a life outside of family relationships (Brainerd 2000). Therefore, Margarita found herself in a condition of economic hardship. This situation, and particularly the fact that her family regarded it as shameful, played an important role in determining her departure from Ukraine: "I was in trouble. I mean, I was not so well dressed, you could see that ... this wage was not enough. And she [my sister] said 'go for one or two months and I'll make you a passport. ... We are so ashamed that you stay like this.'”

After a period spent sleeping on the streets, Margarita found employment in a hotel in Southern Italy. Since she was undocumented (her travel visa had expired), her employers did not provide her with a contract, entrapping her in an exploitative labor relationship. Isolation and a lack of a social network played an important role in the violations to which Margarita was subjected. She worked, on average, sixteen hours a day, without a rest day or public holidays, for a salary of 400 euros per month. Margarita's vulnerability was also linked to her need to pay off the travel debt she owed to her sister; she used all the money she earned for this, saving just a small amount for her needs.

Like many foreign women living in Italy, particularly Ukrainians, Margarita was the victim of sexual violence (see ISTAT 2015). In her case, the perpetrator was her employer. Because of her resistance to this violence, Margarita had to leave her workplace immediately and find another job and a place to stay. This was not easy. The jobs she found were not well paid, and in some cases the employers did not pay her at all, taking advantage of her undocumented status. Thus, Margarita's account unveils how the production of "illegality" - as a juridical status but also a spatialized, racialized (De Genova 2002), and gendered (Abrego 2013) sociopolitical condition-provides an apparatus for creating and sustaining undocumented migrants' "vulnerability and tractability as workers" (De Genova 2002, 439), as well as their oppression through heteropatriarchal violence. As she explained: "It's a bit difficult, it has always been like this. People exploit you because of these documents and ... I could not say anything . . because I was always afraid they would send me back home."

Apprehended due to her undocumented status, Margarita was held for nine hours by police officers, who treated her disparagingly and asked ques- 
tions of an intimate nature. As in the case of Najwa, Margarita was asked to sign papers written in Italian, the meaning of which she could not completely understand. Furthermore, she was denied the right to make a phone call to a lawyer. Only when inside the detention center did Margarita fully realize what was happening to her and where she had been taken.

\section{Exploitation and violence in intimate relationships}

I went to the hospital ... but I had to say that I had fallen from the scooter.

-Desirée's story

Scholars such as Eithne Luibhéid (2005, 2008a, 2008b) have stressed how the preference for heterosexual marriage as a means of legalization has structured Western immigration systems. Such anxious (re)production of heteronormativity, in Luibhéid's view, not only serves to uphold patriarchal gender and sexual regimes but also works to perpetuate hierarchies based on race, class, and nation. Furthermore, Luibhéid claims, recognized couple relationships have to be understood as a technology for the state and its assemblages to "transform legally admitted immigrants into 'good' neoliberal citizenswhile threatening those who do not measure up with potential illegalization" (2008a, 180-81). In particular, it is worth noting that this family preference system creates an unequal power relationship between the partners so that one - usually the woman - becomes dependent on the other for the recognition of her status and rights. Such a state of affairs provides fertile ground for the growth of abusive relationships (see Narayan 1995), such as the one experienced by Desirée.

Desirée, a twenty-four-year-old Cuban woman, reported that she left Cuba due to an engagement, in this case with an Italian man many years her senior. During her interview, Desirée recounted the constraints and poor living conditions she experienced in Cuba, describing how she decided to work in a nightclub to help her mother, who single-handedly carried the financial burden of the family. Economic hardship and the lack of opportunities to live a free and full life were both crucial in her decision to leave. In Desirée's case, upon arriving in Italy she married her Italian partner and requested a family residence permit. Triggered by jealousy over her quest for autonomy, Desirée's husband began to beat her. As in the case of Margarita, Desirée's perpetrator exploited the vulnerability resulting from her migrant status, forcing her to suffer the abuse in silence. "He never left me alone," Desirée revealed. "He [threatened me; he] said that if I said it was him [who beat me, since] I was without a residence permit, he would go to the 
police station and make a report." Thanks to her personal strength, and by relying on the support of a compatriot woman, Desirée managed to leave the marital home. In so doing, she asserted her right to a dignified life, free from violence. When she left, her husband alerted the police.

After Desirée left the house of her abusive partner, the Naples questura (police headquarters) notified her that her application for a family residence permit had been denied. She was held in the police station for seven hours locked inside a room without food and water, without receiving any explanation. The only information given to her was that she would be deported to Cuba. In addition, Desirée reported that a police officer called her bucchina, a derogatory Neapolitan term that refers to someone who performs oral sex and is vulgarly used to mean "bitch": "I sat down, they locked the door.... No food, no nothing ... and without any explanation. ... The only thing they did was the compliment [ironic] of calling me bucchina. 'It is clear what this "bucchina" wants to do, she is sly.'" Using her mobile phone, Desirée managed to call her lawyer, who went to the police station, but she was not allowed to meet with him. However, before she was taken to Rome's detention center, she managed to provide him with the documents given to her by the police.

\section{Citizenship as a means of inclusive exclusion}

At the camp there are two gates: from one I enter, I greet my relatives, and from the other I go out, because I get upset, I feel bad.

- Mirela's story

A particular case is that of Romani women who, although many have been born and raised in Italy, are legally produced as noncitizens and thus exposed to control, repression, and exclusion. ${ }^{12}$ This differential access to citizenship reveals how borders extend inside and outside Europe, both drawing territorial delimitations between states and marking differences between individuals (Rigo 2005; Andrijasevic 2010). Such "boundaries of status" (Rigo 2005, 12) work to produce certain categories of people as dispossessed subjects, heightening their levels of vulnerability. In the case of Romani communities living in Italy, the concept of nomadism, along with the stereotypical image of Roma as a dangerous group, has also played a

${ }^{12}$ Approximately 55 percent of the 180,000 Roma and Sinti estimated to be living in Italy were born in Italy, but many are not recognized as Italian citizens. This is because Italian citizenship law is largely based on jus sanguinis (right of blood) rather than jus soli (right of soil). As a consequence, children born in Italy to nonnationals do not acquire Italian citizenship at birth. 
key role in creating conditions of exposure and precarity, which has been instrumental in the development of an institutionalized segregation policy (Sigona 2005). ${ }^{13}$ The housing of Roma in camps, as emphasized by the UN Committee on the Elimination of Racial Discrimination (CERD 1999, 3 ), has led "not only to a physical segregation of the Roma community from Italian society, but a political, economic and cultural isolation as well."

In this context, Romani women endure a multifaceted oppression as a result of racialized, classed, and gendered mechanisms of subjugation. As Alexandra Oprea, a Romanian Romani activist, points out "race, class, and gender dynamics place Romani women in a precarious position, the consequences of which are often early marriage, lack of access to decent labour, healthcare, and education, and increased vulnerability to domestic violence" $(2004,33)$. The intersections of racism, sexism, and poverty also limit Romani women's access to the political sphere. And when such access is arduously obtained, their voices are often muffled and the specificity of their experiences erased (Oprea 2004). The multiple discrimination faced by Romani women, which heightens their exposure to violence, emerges in Mirela's story.

Mirela, a thirty-three-year-old Romani woman born in Rome to Serbian parents, reported that when she was a child, her family was evicted from the apartment they owned and had to move to a so-called nomad camp. Like many Romani children living in the camps, Mirela never had access to a proper education, and thus she was denied the opportunity to break the cycle of poverty in which she grew up. When she turned eighteen and lost the legal protection derived from being a minor, she became undocumented (see Sigona 2016). Mirela also described her experience of intimate relationships as being marked by gender violence from which she was able to escape thanks to the support of her mother. At nineteen years old she had a daughter, who became her main reason to strive for a better life. Mirela consequently began to toil as an irregular domestic worker in private households, being exposed to harsh and exploitative working conditions. "I have always worked but always without a contract," she said. "Even when I was pregnant I used to work, at six months [of pregnancy] I used to climb up the ladder to clean windows, you know? . . . But I had to do it for money, what else could I do? .. I have always tried to give my daughter everything she needed."

Mirela was ultimately caught during a police raid inside a Romani camp. Found without documents, she was taken to the police station. Police officers told her that it was just a "control" and that they would later bring her back to

${ }^{13}$ In Italy around forty thousand Roma and Sinti reside in so-called nomad camps (Associazione 21 Luglio 2015). 
the camp. In truth, she spent a day and a night in the police station, until she was taken to Rome's detention center without much explanation. In her account Mirela described the mistreatment received at the hands of the two officers, and how she fought to claim her right to dignified treatment.

In spite of the differences among them, all of these stories highlight the precarity of these women's lives, which is a consequence of the intersection between multiple and contingent relations of power. Entering the country as documented through official channels, or even being born in the country (Italy), did not prevent our participants from being produced as "illegal" by restrictive immigration and citizenship regulations (see Andrijasevic 2009). As a consequence, they were trapped in a "space of forced invisibility, exclusion, subjugation, and repression" (De Genova 2002, 427), a space shaped by the persistent experience of deportability. This imposed condition of vulnerability intersected with — and at the same time was produced by - hierarchies of sexuality and gender, along with race, class, and nationality (among other factors), which structured their positions both in the labor market and in intimate relationships (Sager 2016), maximizing their exposure to violence, abuse, and exploitation.

As Judith Butler, Zeynep Gambetti, and Leticia Sabsay (2016) passionately argue, the uneven distribution of vulnerability, which makes some people more exposed to arbitrary violence than others, is the constituent of contemporary precarity. Yet, on the other hand, vulnerability is also one of the conditions of people's possibility of resistance. In Butler's words, vulnerability, as "a relation to a field of objects, forces, passions that impinge upon or affect us in some way" $(2016,25)$, can be understood "as part of the very meaning of political resistance as an embodied enactment" (22). Consistent with this view, the women we met created strategies to cope with and resist the precariousness that threatened the lives they were building. They engaged in struggles for justice and recognition, challenging the state and its functionaries. In so doing, and to counteract the violence they were forcibly subject to, including police brutality, they often relied on family ties, such as the daughter-mother relationship, as well as on relationships formed with people navigating similar difficulties, often compatriot women. When such ties were lacking - as in the case of Margarita - it was harder for the women to react. This sheds light on the importance of establishing networks of solidarity from below in order to challenge regimes of oppression.

\section{The apparatus of immigration enforcement}

Undocumented women have to strive on a daily basis to make their own way in Europe. In so doing, they seek legitimate subject positions and make use 
of existing legal tools. However, as Luibhéid (2005, xvii) notes, these tools, such as that of asylum, are constructed so as to be accessible only to a select minority of people, usually "those who are male, heterosexual, economically privileged, and from particular 'racial' and national origins." As a consequence, the vast majority of these women are produced as "ineligible," and, not being entitled to any kind of protection and legal status, they are exposed to arrest, incarceration (often for extensive periods and in very harsh conditions), and finally, deportation (see Bhabha 2002). This was also the fate of the women we met in the Ponte Galeria detention center.

\section{Migration-related detention}

In detention centers, gender, sexuality, and race shape women's everyday lives (Bosworth and Kellezi 2014). As Gabriella Alberti (2010) notes, the detention regime serves to reinforce traditional gender identities and reproduce women's vulnerability. In so doing, it erases the political dimension of women's experiences and undermines their agency as political subjects (Freedman 2015).

Our participants' narratives provide support for this argument. According to heteropatriarchal norms, women were symbolically divided into "good" and "bad" within Rome's detention center. Good women were the "harmless" ones, those who did not make trouble for the staff and who fit within the hegemonic notion of femininity. In contrast, bad women were "troublesome"; they transgressed traditional gender and sexual roles, and staff found them difficult to manage.

As a means by which the staff managed the "'hyper-diversity' of the detention population" (Bosworth 2012, 133), nationality was further used to articulate such stereotypical divisions in a racialized way. For instance, Russians, Ukrainians, and Georgians were regarded as quiet and disciplined detainees, women who had come to Italy to do the domestic and care work that Italian women are no longer able to do because of their increasing participation in the labor market. In contrast, Nigerian women, who often made their living as sex workers, were considered aggressive and hypersexualized. As Precious reported: "They see Nigerian people and they say what, puttana [whore ]... they'll look at you." The notion of "good" and "bad" was deeply intertwined with the concept of women's victimhood and dangerousness and, subsequently, with the idea of whether or not they deserved to be detained. While "good" women, perceived as vulnerable, were regarded as victims of the detention system, the others-sex workers, queers, Roma, and ex-prisoners - were regarded as dangerous subjects who deserved to be locked up and expelled. 
Racialized stereotypical views were also shared by detained women, who often classified the other detainees based on their understanding of nationality. For instance, Mirela described Nigerian women as noisy and inclined to bully other detainees, while Precious complained about the self-segregating attitude of the Chinese. Interestingly, the participants' narratives revealed a constant tension between membership based on the sharing of a national identity and a sense of belonging to the larger community of detainees (Bosworth 2014). In particular, some participants criticized the accommodation of detainees in the sleeping rooms according to ethnic/racial criteria. Desirée said: "Basically it is they [the staff] who are making a difference. Not the girls. It is the ones who are working here. Putting the African in one place, the Chinese in another."

Regardless of nationality and individual backgrounds, all the women described everyday life inside Rome's center as very difficult. They complained about the living conditions, mentioning the poor hygiene of the detention area, the poor quality of the food, and, above all, the total lack of activity as the main critical issues. Having no activities, women spent their time smoking, watching TV, speaking on the phone, chatting, and, most of all, thinking about their situation. Inactivity and stress had a profound impact on their psychological well-being. Mirela reported: “The first time I arrived here, I didn't sleep for three days, even taking drugs. I couldn't stand it anymore, I looked like a zombie."

For all the women, the main challenge was the very fact of giving meaning to their detention experience. Given that they had not committed any crime, they argued for the illegitimacy of confinement based on administrative grounds. Lack of information regarding the management and possible outcomes of their immigration cases and uncertainty regarding the time to be spent inside the center only served to further complicate the picture. "For a woman to come here," Najwa said, "facing her problems in her life and she ends up here, ... like you know the place looks scary, like you can see by yourself, you know? And you can never understand that . . . even if you only think about that: 'I'm gonna stay here for six months or even for one month' ... in this place it's totally unacceptable [to stay]."

Uncertainty and instability are constitutive dimensions of the detention experience and thus become tools of governmentality (Griffiths 2014). As Melanie B. E. Griffiths $(2014,1994)$ observes, "much of this temporal 'angst' relates to the perceived disjuncture between the temporalities of themselves and those around them, and between their expectations of progress and efficiency, and the machinations of the immigration and judicial systems in practice." Without knowing how long they will remain in detention, it is difficult for the women to imagine their future (Griffiths 2014). 
Such experiences of temporal violence cause profound emotional suffering (Lewis 2013). "You know when you enter," Mirela said, "but you never know when and how you get out! Indeed, now I'm fighting with my mind: 'What will happen to me?' "In spite of the precariousness produced by the detention system, the women we met strived to resist. They denounced the unfairness of such a system and made claims for rights and entitlements. To do so, they relied on normative expectations of femininity and female respectability. Mirela reported: "I have been without a bra for three days. Until I tell them: 'Excuse me, but with the nipples like this how can I present myself in front of the judge?' I'm not saying you need makeup, I'm not saying you need to overdress, [but] you have to go there like all humans. And without a bra I'm not accustomed, I say: 'Give me my bra.' They removed the underwires and they gave it back to me."

Some women, like Desirée, identified detention centers with prisons. Others, like Mirela, remarked that prisons are better, because "at least you know it, you're imprisoned, you made a mistake, they give you seven, eight months and you get out." Despite the different-albeit intertwined — visions, for all participants the main aim was freedom.

In fact, it is with the aim of claiming such a right that many protests are begun in detention. A meaningful example in this sense was the protest against Law No. 129/2011 (which extended the maximum term of detention from six to eighteen months) that broke out in August 2011 in Bologna's detention center. The protest began with a hunger strike at lunchtime, when Nigerian women refused food and demanded freedom, which was followed by the burning of mattresses. To crush this protest, around fifteen police officers burst into the living unit. In the clashes that followed, some women were hurt (Del Grande 2011).

Speaking about their experience inside Rome's center, all of our participants reported a strong feeling of sisterhood. In the midst of their differences, the shared experience of confinement allowed them to bond on the basis of "feeling-with" one another (O'Donnell 2007, 101). All interviewees described the connections they formed with women from different backgrounds and experiences as the most positive aspect of detention (Bosworth and Kellezi 2014). "The only thing is that you make friends with new girls who otherwise ... you might not know outside," Mirela said. The "freedom song" described by Precious provides an example of women's sisterhood. The song, particularly common among Nigerian women, was used to celebrate the release of detainees. When the news of a release was communicated by immigration authorities, and usually shared by the woman concerned with cries of joy, the other detainees began to leave their rooms and gather in the corridor of the living unit to start singing. Although Nigerian women lead 
this celebration, women of other nationalities usually followed. This ritual helped them bond through the joy of newfound freedom. As Sarah Hughes (2016) emphasizes, music, rhythm, and improvisation "can be considered political in their very unknowability, as they challenge and resist the certainty of the production of a governable political order." The paintings and graffiti detainees made on the walls of the living unit to challenge the grayness and impersonality of the detention environment represented another expression of the women's political agency.

Among the women, the main resource to cope with detention was solidarity. Many of our participants reported how, in the very first days, they did not have access to a phone and only managed to call their families or lawyers thanks to other detainees' mobile phones. ${ }^{14}$ Furthermore, they recounted how information concerning the center's rules, not (or only partially) provided by staff members, were shared by the women who had spent a longer time in detention.

Our participants' accounts of their detention experiences also revealed the women's determination to claim their rights. In particular, some participants expressed the desire to write down their stories and those of the other women they had met. As Najwa remarked: "I've seen a lot of people who suffered throughout this experience, and it's really bad. Like I understand that Europeans when they have refugees in their country, I understand that they're not gonna be happy with it . . but they didn't live throughout this. I experienced this with my own ... and I think I'm gonna write a book about that." Rewriting her own story, and recounting the suffering, struggles, and challenges faced as an undocumented woman, is an act of resistance that carries a strong potential for political transformation (Gready 2003). Survivors' firsthand accounts of their detention experiences, as counternarratives, are indeed crucial tools to challenge the dominant security discourse on migration (Wibben 2011).

\section{Deportation}

Two of our participants also recounted previous experiences of deportation to their countries of origin. Such experiences were described as profoundly violent and distressing, and were self-evidently gendered and sexualized (Ratia and Notermans 2012).

In 2010, after twelve days of detention in Rome's center, Mirela was deported to Belgrade, a city that she did not know, having being born and lived

\footnotetext{
${ }^{14}$ Only mobile phones without cameras are allowed inside Rome's center, and several days can pass before the center's staff can purchase one for a new detainee.
} 
all her life in Italy. Mirela described the deportation experience as a terrible ordeal and reported having been treated like a criminal. Having no one to call and nowhere to go in Belgrade, Mirela found a park to sleep in. There, two men kidnapped her. After three months, during which she was exposed to abuse, rape, and sexual exploitation on a daily basis, she managed to run away.

Speaking about her deportation to Nigeria in 2013, Precious reported how she was caught in an ambush. When police officers came to take her inside Turin's detention center, Precious struggled to resist, claiming her right to take her daughter, who had been left against her will in the hospital, with her: "It was violent, because when they came I was surprised, ... they ambushed ... they came ... they just called me: 'You have to go now.' ... I said, 'Okay, if you want to take me now give me my baby.' "

Nigerian migrants are often collectively deported in Italy, revealing the relevance of nationality in maximizing exposure to arbitrary state violence. This practice is based on a bilateral agreement between the Italian and $\mathrm{Ni}$ gerian governments, under which the Nigerian Consulate conducts rapid interviews for identification purposes in order to allow the Italian immigration authorities to forcibly deport "irregular" Nigerian nationals. ${ }^{15}$ Lawyers and civil society representatives have largely contested this practice, regarding it as a serious violation of human rights. Of interest in this regard is the case of the sixty-six Nigerian women, many of whom had been exposed to abuse and violations while detained in Rome's center in the summer of 2015 (see Beretta et al. 2016). These women were detained immediately (or a few days) after landing on the coast of Sicily, without being provided with any information about the possibility of seeking humanitarian protection. Moreover, at the very moment of their entry into Ponte Galeria, they were collectively identified by the Nigerian consul in order to be forcibly deported back to Nigeria within a few days. ${ }^{16}$ Individuals and migrants' rights organizations have denounced the case and struggled to prevent the deportation of the women, only partially succeeding. The resistance, even physical, put in place by the women themselves on the day of the deportation was crucial in order to give activists and lawyers extra time to intervene. Despite an arduous collective struggle, around twenty women were boarded onto a Frontex flight and deported to Lagos.

As Rachel Lewis (2013) observes, when migrants are given little or no warning of their deportation, and no time to contact their lawyers, their

\footnotetext{
${ }^{15}$ Such agreements have also been formalized with other countries, including Egypt, Tunisia, Morocco, and, more recently, Sudan.

${ }^{16}$ It is worth noting that none of them had a copy of the expulsion order issued against them.
} 
only option is to rely on their physical ability to resist. In Ponte Galeria, such "everyday acts of resistance" (Lewis 2013, 185) are quite common. Significant in this regard are the words of Biljana, a twenty-five-year-old Montenegrin woman we met during our fieldwork, who described a collective deportation she had witnessed: "They were taking them back to their country, and the Africans did not want to go. ... Police officers came, militaries, everybody had that truncheon to beat them, and the Africans were beating [the police officers] and [the police officers] were beating the African women. . . . They [the women] took off their shirts so they could not be held. Everyone was fighting naked."

Following her attempt at resistance, Precious was handcuffed and carried onto the plane by force. Once in Lagos she was taken into custody by the Nigerian authorities, who asked her for money to be released. Life in Nigeria after the deportation was not easy for Precious, who like many deported migrants faced the stigma of failure and contamination in her country of origin (Schuster and Majidi 2015). Nigerian women with experiences of sex work are particularly likely to be stigmatized and ostracized (Ratia and Notermans 2012). This evidence highlights the role of sexuality and gender in shaping women's experiences of forced return.

It is worth noting that both Precious and Mirela challenged the gendered disruptions brought about by deportation (Ratia and Nothermans 2012). Both found a way to migrate back to Italy. However, once in Italy, they were both detained again. It was during this second detention that our interviews took place.

\section{Conclusion}

In the face of increasing control and criminalization of human mobility, feminist scholars have argued that it is important "to hear and understand women's voices with respect to borders and border crossings" (Mehta 2016, 288). Too often, these voices have been silenced, while migrants have been constructed as an undifferentiated category of undesirable subjects whose "illegality" is a sign of their character rather than an outcome of larger structural processes and histories of inequality (Luibhéid 2008b).

Scholars engaged in the study of everyday life inside detention centers have called particular attention to the almost nonexistent body of knowledge concerning women's experiences in detention (for exceptions, see Alberti 2010; Bosworth, Fili, and Pickering 2014; Bosworth and Kellezi 2014). The purpose of this article is to contribute to filling this gap, in the belief that a feminist understanding of such experiences, rooted in the marginality 
of these women's positions, can open up new lines of thought (Bosworth, Fili, and Pickering 2014; Mehta 2016).

From this standpoint, and consistent with Lykes and Hershberg (2015, 260 ), our analysis has sought to provide a platform for women's "powerful narratives of suffering, survival, protagonism and resistance." In particular, in order to represent the "hyper-diversity" (Bosworth 2012, 133) of the population confined inside Rome's center, we chose to present the stories of five women with very different life trajectories. We have presented these stories in a sociopolitical and historical context, showing how-in spite of individual differences - women's experiences of oppression and resistance-in their countries of origin, transit, and settlement-are deeply intertwined and strongly influenced by structural realities. Moreover, their stories reveal the role of gender and sexuality in relation to other hierarchies of power such as class, race, nationality, and geopolitics, in shaping women's international migration to and incorporation into Europe.

Several reflections can be drawn from our work. First, we can consider the operation of immigration and border control regimes and how these both reflect and further entrench the normative power hierarchies in society at large (Luibhéid 2005; Lewis and Naples 2014). In so doing, as Luibhéid $(2005$, xiv) argues, these regimes work “to ensure a 'proper' sexual and gender order, reproduction of white racial privilege, and exploitation of the poor." Furthermore, they manifest and engender dominant notions of citizenship and nation sovereignty (Andrijasevic 2010).

In this process, as our analysis highlights, a key role is also played by instruments ideally designed to safeguard human rights, such as that of asylum, that perpetuate the dispossession of racialized and gendered bodies (Butler and Athanasiou 2013). All of the women whose stories are recounted in this article experienced forms of gender-based violence, but none of them had access to any form of protection since they fell outside of the narrow categories recognized by the state. As a result, they were produced as "illegal," and by extension deportable subjects, exposed to abuse, exploitation, confinement, and death.

However, women were not passive spectators of the violence perpetrated by the nation-state; rather, they struggled to resist it. Within the limited opportunity structures and spaces available to them, they built their everyday lives, making claims and actively negotiating their multiple and often contradictory positionings. ${ }^{17}$ In this view, according to Catherine Campbell and Jenevieve Mannell $(2016,1)$, their agency can be understood as a "multi-

\footnotetext{
${ }^{17}$ For further work on this topic, see also Rutvica Andrijasevic's (2010) study of migrant women working in the sex industry.
} 
level, incremental and non-linear process distributed across time, space and social networks, and across a continuum of action ranging from survival to resistance." Such a nuanced way of thinking about power and agency sheds light on the numerous ways in which women deal with the different regimes of power that oppress them. It also acknowledges the complexities, tensions, and contradictions that characterize their lives (see Shefer 2015).

For instance, the participants' accounts of everyday life inside Rome's center shed light on how women - sometimes simultaneously - accepted, manipulated, negotiated, and contested the racial, gender, and sexual norms that structure the regime of detention management. Further, these accounts highlight the importance of sisterhood and solidarity as resources upon which the women relied to cope with detention, as well as "to resist and undermine the deportation machine" (Campesi 2015, 429).

We would like to conclude by joining Eithne Luibhéid's call for a scholarship and an activism able "to challenge and transform the relations of power that operate through migration regimes to generate unequal regimes of living and dying at multiple scales" (Luibhéid 2008a, 183). We hope that, by exploring the processes through which certain lives are produced as devalued and ungrievable (Butler 2009), this article can contribute to this aim, pointing to the need for a transnational feminist project that acknowledges the value of diversity and difference (Mohanty 2003) while featuring "modes of response and solidarity that do not reify 'the dispossessed' and thus do not repeat the erasing of their singularity" (Butler and Athanasiou 2013, 136). Such a project-based on the creation of political and affective alliances among people whose lives are differently affected by the violence of multiple borders and boundaries - should acknowledge vulnerability as a common resource (Butler, Gambetti, and Sabsay 2016). Further, it should be rooted in the belief that free movement, as a precondition for human freedom to truly live (De Genova 2010), should not be reserved for a privileged few but rather is equally deserved by all.

APPsyCI (Applied Psychology Research Center Capabilities and Inclusion ISPA-University Institute (Esposito and Ornelas)

Department of Dynamic and Clinical Psychology, Sapienza

University of Rome (Scirocchi)

Department of Humanities

University Federico II of Naples (Arcidiacono) 


\section{References}

Abrego, Leisly J. 2013. "Latino Immigrants' Diverse Experiences of 'Illegality.'” In Constructing Immigrant "Illegality": Critiques, Experiences, and Responses, edited by Cecilia Menjívar and Daniel Kanstroom, 139-60. Cambridge: Cambridge University Press.

Alberti, Gabriella. 2010. "Across the Borders of Lesvos: The Gendering of Migrants’ Detention in the Aegean." Feminist Review, no. 94: 138-47.

Amnesty International. 2015. “' 'Libya Is Full of Cruelty': Stories of Abduction, Sexual Violence, and Abuse from Migrants and Refugees.” Report. http://www.amnesty .eu/content/assets/Reports_and_Briefings_2015/Libya_is_full_of_cruelty.pdf.

Andrijasevic, Rutvica. 2009. "Sex on the Move: Gender, Subjectivity, and Differential Inclusion.” Subjectivity 29(1):389-406.

. 2010. Migration, Agency, and Citizenship in Sex Trafficking. Basingstoke: Palgrave Macmillan.

Associazione 21 Luglio [July 21 Association]. 2015. "Rapporto Annuale 2015" [Annual report]. http://www.21luglio.org/wp-content/uploads/2016/04 /Rapporto_annuale_2015_def_web.pdf.

Beretta, Lucia, Loretta Bondi, Francesca De Masi, Francesca Esposito, Federica Festagallo, Oria Gargano, and Carla R. Quinto. 2016. Inter/rotte: Storie di tratta, percorsi di resistenze [Inter/rupted: Stories of trafficking, paths of resistance]. Rome: Sapere Solidale.

Bhabha, Jacqueline. 2002. "Internationalist Gatekeepers? The Tension between Asylum Advocacy and Human Rights." Harvard Human Rights Journal, no. 15: 155-81.

Bosworth, Mary. 2012. "Subjectivity and Identity in Detention: Punishment and Society in a Global Age." Theoretical Criminology 16(2):123-40.

- 2014. Inside Immigration Detention. Oxford: Oxford University Press.

Bosworth, Mary, Andriani Fili, and Sharon Pickering. 2014. "Women's Immigration Detention in Greece: Gender, Control, and Capacity." In Immigration Detention, Risk, and Human Rights, edited by Maria João Guia, Robert Koulish, and Valsamis Mitislegas, 157-70. New York: Springer.

Bosworth, Mary, and Blerina Kellezi. 2014. "Citizenship and Belonging in a Women's Immigration Detention Centre." In New Directions in Race, Ethnicity, and Crime, edited by Coretta Philips and Colin Webster, 80-96. Abingdon: Routledge.

Brainerd, Elizabeth. 2000. "Women in Transition: Changes in Gender Wage Differentials in Eastern Europe and the Former Soviet Union." ILR Review 54(1):13862.

Butler, Judith. 2009. Frames of War: When Is Life Grievable? New York: Verso.

. 2016. "Rethinking Vulnerability and Resistance." In Butler, Gambetti, and Sabsay 2016, 12-27.

Butler, Judith, and Athena Athanasiou. 2013. Dispossession: The Performative in the Political. Cambridge: Polity. 
Butler, Judith, Zeynep Gambetti, and Leticia Sabsay, eds. 2016. Vulnerability in Resistance. Durham, NC: Duke University Press.

Campbell, Catherine, and Jenevieve Mannell. 2016. "Conceptualising the Agency of Highly Marginalised Women: Intimate Partner Violence in Extreme Settings." Global Public Health 11(1-2):1-16.

Campesi, Giuseppe. 2015. "Hindering the Deportation Machine: An Ethnography of Power and Resistance in Immigration Detention." Punishment and Society 17 (4):427-53.

CERD (UN Committee on the Elimination of Racial Discrimination). 1999. "Concluding Observations, Italy." Report. United Nations, Geneva. http://www .refworld.org/publisher,CERD,CONCOBSERVATIONS,ITA,3ae6af357,0 .html.

De Genova, Nicholas. 2002. "Migrant 'Illegality' and Deportability in Everyday Life." Annual Review of Anthropology 31:419-47.

- 2010. "The Deportation Regime: Sovereignty, Space, and the Freedom of Movement." In The Deportation Regime: Sovereignty, Space, and the Freedom of Movement, edited by Nicholas De Genova and Nathalie Peutz, 33-65. Durham, NC: Duke University Press.

Del Grande, Gabriele. 2008. "Niger: I rifugiati denunciano gli abusi subiti nel Sahara" [Niger: Refugees denounce the abuses suffered in the Sahara]. Bologna: Fortress Europe, July 29. http://fortresseurope.blogspot.pt/2006/01/niger-i-rifugiati -sbarcati-in-italia.html.

_ 2011. "CIE Bologna: Protesta al femminile, 3 donne picchiate" [Bologna's CIE: Protest in the female living unit, 3 women beaten]. Fortress Europe, August 24. http://fortresseurope.blogspot.pt/2011/08/cie-bologna-protesta-al -femminile-3.html.

Esposito, Francesca. 2017. "Practicing Ethnography in Migration-Related Detention Centers: A Reflexive Account." Journal of Prevention and Intervention in the Community 45(1):57-69.

Esposito, Francesca, José Ornelas, and Caterina Arcidiacono. 2015a. "MigrationRelated Detention: A Focus on the Italian Context." In The Borders of Schengen, edited by Alice Cunha, Marta Silva, and Rui Frederico, 177-91. Brussels: Peter Lang.

_ 2015b. "Migration-Related Detention Centers: The Challenges of an Ecological Perspective with a Focus on Justice." BMC International Health and Human Rights 15(13):1-15.

Freedman, Jane. 2015. Gendering the International Asylum and Refugee Debate. Basingstoke: Palgrave Macmillan.

Galtung, Johan. 1969. "Violence, Peace, and Peace Research." Journal of Peace Research 6(3):167-91.

Gerard, Alison, and Sharon Pickering. 2014. "Gender, Securitization, and Transit: Refugee Women and the Journey to the EU." Journal of Refugee Studies 27(3): 338-59.

Gready, Paul. 2003. Writing as Resistance: Life Stories of Imprisonment, Exile, and Homecoming from Apartheid South Africa. Lanham, MD: Lexington. 
Griffiths, Melanie B. E. 2014. "Out of Time: The Temporal Uncertainties of Refused Asylum Seekers and Immigration Detainees." Journal of Ethnic and Migration Studies 40(12):1991-2009.

Harding, Sandra, ed. 2004. The Feminist Standpoint Theory Reader: Intellectual and Political Controversies. New York: Routledge.

Hughes, Sarah. 2016. "Creativity and Resistance within UK Immigration Removal Centres.” Border Criminologies, May 11. https://www.law.ox.ac.uk/research -subject-groups/centre-criminology/centreborder-criminologies/blog/2016 $/ 05 /$ creativity-and.

Hyndman, Jennifer. 2000. Managing Displacement: Refugees and the Politics of Humanitarianism. Minneapolis: University of Minnesota Press.

IOM (International Organization for Migration). 2017. "Mediterranean Migrant Arrivals Reach 83,928 in 2017; 2,108 Deaths.” Press release, June 23. https:// www.iom.int/news/mediterranean-migrant-arrivals-reach-83928-2017-2108 -deaths.

ISTAT (Istituto Nazionale di Statistica; National Institute of Statistics). 2015. "La violenza contro le donne dentro e fuori la famiglia" [Violence against women inside and outside the family]. Report, June 15. http://www.istat.it/it/files/2015/06 $/$ Violenze_contro_le_donne.pdf?title $=$ Violenza + contro + le + donne $+-+05 \% 2$ Fgiu $\% 2 \mathrm{~F} 2015+-+$ Testo+integrale.pdf.

L'amore ai tempi della frontiera [Love in the time of the frontier]. 2012. Directed by Alexandra D'Onofrio. Bologna: Fortress Europe.

Lewis, Rachel. 2013. "Deportable Subjects: Lesbians and Political Asylum.” Feminist Formations 25(2):174-94.

Lewis, Rachel, and Nancy Naples. 2014. "Introduction: Queer Migration, Asylum, and Dsplacement." Sexualities 17(8):911-18.

Luibhéid, Eithne. 2005. Queer Migration: Sexuality, U.S. Citizenship, and Border Crossings. Minneapolis: University of Minnesota Press.

—. 2008a. "Queer/Migration: An Unruly Body of Scholarship." GLQ 14(23):169-90.

- 2008b. "Sexuality, Migration, and the Shifting Line between Legal and Illegal Status.” GLQ 14(2-3):289-315.

Lykes, M. Brinton, and Rachel M. Hershberg. 2015. "Continuities and Discontinuities in Human Rights Violations: Historically Situating the Psychosocial Effects of Migration." Journal of Social Issues 71(2):244-63.

MacLeod, Arlene Elowe. 1992. "Hegemonic Relations and Gender Resistance: The New Veiling as Accommodating Protest in Cairo." Signs: Journal of Women in Culture and Society 17(3):533-57.

Mehta, Rimple. 2016. "Borders: A View from 'Nowhere.'” Criminology and Criminal Justice 16(3):286-300.

Mohanty, Chandra Talpade. 1995. "Feminist Encounters: Locating the Politics of Experience." In Social Postmodernism: Beyond Identity Politics, edited by Linda Nicholson and Steven Seidman, 68-86. Cambridge: Cambridge University Press. 
2003. Feminism without Borders: Decolonizing Theory, Practicing Solidarity. Durham, NC: Duke University Press.

Mountz, Alison. 2011. "Where Asylum-Seekers Wait: Feminist Counter-topographies of Sites between States." Gender, Place, and Culture 18(3):381-99.

Narayan, Uma. 1995. “'Male-Order’ Brides: Immigrant Women, Domestic Violence, and Immigration Law." Hypatia 10(1):104-19.

O’Donnell, Carolynn. 2007. "A Philosophical Account of Feminist Solidarity between Women." Senior thesis, Mount Holyoke College.

Oprea, Alexandra. 2004. "Re-envisioning Social Justice from the Ground Up: Including the Experiences of Romani Women." Essex Human Rights Review l(1):2939.

Personal Narratives Group, ed. 1989. Interpreting Women's Lives: Feminist Theory and Personal Narratives. Bloomington: Indiana University Press.

Ratia, Emma, and Catrien Notermans. 2012. "'I Was Crying, I Did Not Come Back with Anything': Women's Experiences of Deportation from Europe to Nigeria." African Diaspora 5(2):143-64.

Riessman, Catherine Kohler. 2008. Narrative Methods for the Human Sciences. Thousand Oaks, CA: Sage.

Rigo, Enrica. 2005. "Citizenship at Europe's Borders: Some Reflections on the Postcolonial Condition of Europe in the Context of EU Enlargement." Citizenship Studies 9(1):3-22.

Robjant, Katy, Ian Robbins, and Victoria Senior. 2009. "Psychological Distress amongst Immigration Detainees: A Cross-Sectional Questionnaire Study." British Journal of Clinical Psychology 48(3):275-86.

Sager, Maja. 2016. "Constructions of Deportability in Sweden: Refused Asylum Seekers’ Experiences in Relation to Gender, Family Life, and Reproduction.” NORA 24(1):30-44.

Schmoll, Camille. 2014. "Gendered Spatialities of Power in 'Borderland' Europe: An Approach through Mobile and Immobilised Bodies." International Journal of Migration and Border Studies 1(2):173-89.

Schuster, Liza, and Nassim Majidi. 2015. "Deportation Stigma and Re-migration." Journal of Ethnic and Migration Studies 41(4):635-52.

Shefer, Tamara. 2015. "Resisting the Binarism of Victim and Agent: Critical Reflections on 20 Years of Scholarship on Young Women and Heterosexual Practices in South African Contexts." Global Public Health 11(1-2):211-23.

Sigona, Nando. 2005. "Locating 'the Gypsy Problem': The Roma in Italy; Stereotyping, Labelling, and 'Nomad Camps.' ' Journal of Ethnic and Migration Studies 31(4):741-56.

- 2016. "Everyday Statelessness in Italy: Status, Rights, and Camps." Ethnic and Racial Studies 39(2): 263-79.

Sobhanian, Farahnaz, Gregory J. Boyle, Mark Bahr, and Tindaro Fallo. 2006. "Psychological Status of Former Refugee Detainees from the Woomera Detention Centre Now Living in the Australian Community." Psychiatry, Psychology, and Law 13(2):151-59. 
Stephen, Lynn. 2008. “Los Nuevos Desaparecidos y Muertos: Immigration, Militarization, Death, and Disappearance on Mexico's Borders.” In Security Disarmed: Critical Perspectives on Gender, Race, and Militarization, edited by Barbara Sutton, Sandra Morgen, and Julie Novkov, 79-100. New Brunswick, NJ: Rutgers University Press.

Turan, Janet M., Abigail M. Hatcher, Patrizia Romito, Emily Mangone, Modupeoluwa Durojaiye, Merab Odero, and Carol S. Camlin. 2016. "Intimate Partner Violence and Forced Migration during Pregnancy: Structural Constraints to Women's Agency." Global Public Health 11(1-2):153-68.

Wibben, Annick. 2011. Feminist Security Studies: A Narrative Approach. Oxon: Routledge.

Zandonini, Giacomo. 2016. "Le rotte della tratta dall' Africa" [The routes of trafficking in Africa]. Inter/rotte: Storie di Tratta, Percorsi di Resistenze [Inter/rupted: Stories of Trafficking, Paths of Resistance], edited by Lucia Beretta, Loretta Bondì, Francesca De Masi, Francesca Esposito, Federica Festagallo, Oria Gargano, and Carla R. Quinto, 19-22. Rome: Sapere Solidale. 